\title{
COMPARISON OF INTRAVASCULAR IMAGING AND QUANTITATIVE CORONARY ANGIOGRAPHY TO EVALUATE NEOINTIMAL PROLIFERATION AFTER COMPLEX LESION STENTING
}

\author{
Sanda Jēgere, Inga Narbute, Indulis Kumsārs, Iveta Mintāle, Ilja Zakke, Dace Juhnēviča, \\ Kārlis Trušinskis, Dace Sondore, Aigars Lismanis, Gustavs Latkovskis, Aḷona Grāve, \\ Andis Dombrovskis, and Andrejs Ërglis
}

Latvian Centre of Cardiology, Pauls Stradiṇš Clinical University Hospital, Rīga, LV-1002, LATVIA

Email: sjegere@apollo.Iv

Communicated by Ludmila Vīksna

\begin{abstract}
Unlike quantitative coronary angiography (QCA), intravascular imaging methods allow direct visualisation of the arterial wall. Our goal was to determine several intravascular ultrasound (IVUS) and optical coherence tomography (OCT) parameters of neointimal proliferation and stent endothelisation after complex lesion intervention compared to QCA. We examined 261 patients who had underwent percutaneous intervention with bare metal (BMS) or drug eluting stent (DES) implantation for complex coronary lesions and had IVUS or OCT images at six-month follow-up. Percent diameter stenosis (QCA) was $25.2 \pm 16.0$ in BMS vs $21.7 \pm 17.4$ in DES $(\mathrm{P}<0.05)$. Percent neointimal volume obstruction (IVUS) was $19.5 \pm 14.4$ in BMS vs. $5.8 \pm 7.7$ in DES (P< 0.001). A moderate correlation was observed between QCA and IVUS with an $r$ value of 0.384 overall, 0.472 for BMS and 0.416 for DES ( $\mathrm{P}<0.001$ for all). In patients with chronic total occlusions $(n=161)$ QCA was similar in BMS and DES patients $(P>0.05)$ while IVUS showed less neointima in DES $(\mathrm{P}<0.05)$. Total number of uncovered stent struts per OCT image was 0.4 \pm 0.8 while per IVUS image $1.2 \pm 1.5(\mathrm{P}<0.001)$. In conclusion, angiographic indexes correlate with volumetric intravascular parameters. Although IVUS was more sensitive than QCA to assess neointimal proliferation, the assessment of stent endothelisation was more precise using OCT.
\end{abstract}

Key words: angiography, ultrasound, complex lesion.

\section{INTRODUCTION}

For many years, quantitative coronary angiography (QCA) has been the gold standard for the assessment of the efficacy of percutaneous coronary intervention (PCI). Moreover it has been routinely used to define endpoints in recent clinical trials (Morice et al., 2002; Mauri et al., 2005). However, these angiographic endpoints are surrogates for intimal hyperplasia, which is the main mechanism leading to in-stent restenosis (Serruys et al., 2006; Weintraub, 2007). With the invention of intravascular imaging methods, direct visualisation of the arterial wall is feasible. Intravascular ultrasound (IVUS) is the oldest catheter-based imaging technology that yields a cross-sectional view of coronary artery from the inside-out using a miniaturised ultrasound transducer (Yock et al., 1989). By colour-coding ultrasound radiofrequency backscatter, IVUS data can be correlated to the vascular histology of the normal and diseased arteries. This method — virtual histology ( $\mathrm{VH})-$ uses algorithms to generate a colour map of the vessel structure content coding for fibrous, necrotic, calcified, and fibro-fatty tissue (Kawasaki et al., 2001; Nasu et al., 2006). Optical coherence tomography (OCT) is optical technology with approximately ten-fold higher resolution than ultrasound-based approaches (Tearney et al., 2003). Intracoronary angioscopy is an endoscopic technology that allows direct visualisation of the surface colour and superficial morphology of atherosclerotic plaque, thrombus, neointima, or stent struts (Honda and Fitzgerald, 2008).

Nowadays both QCA and intravascular imaging methods, mainly IVUS and recently VH and OCT, have been used to assess the safety and long-term efficacy of stenting. Besides neointimal proliferation, we can evaluate delayed endothelisation after stent implantation, which is the main mechanism of stent thrombosis (Joner et al., 2006; Luscher et al., 2007). Previous studies have demonstrated the similarity of QCA and intravascular imaging in low-risk patient population (Escolar et al., 2007). However, there is little data on IVUS versus QCA or OCT comparison after complex lesion stenting (i.e., bifurcations, left main coronary artery disease, chronic total occlusions, saphenous vein grafts) (Semeraro 
et al., 2009). Moreover, the QCA and intravascular image acquisition and quantitative analysis have to be adjusted to patients with complex coronary lesions.

Our goal was to determine several IVUS and OCT parameters of neointimal proliferation and stent endothelisation after complex lesion intervention as compared to QCA indexes to better understand the relative strengths and weaknesses of these parameters.

\section{MATERIALS AND METHODS}

Study population. We searched our PCI registry for patients who had underwent percutaneous coronary intervention with bare metal stent (BMS) or drug eluting stent (DES) implantation for complex coronary lesions - long calcified lesions, chronic total occlusions, bifurcations, and left main coronary artery disease. Patients were eligible for the study if they had follow-up angiography with intravascular imaging (IVUS or OCT) performed six months after PCI. QCA, IVUS and OCT measurements were performed off-line at the Riga core lab blinded to the treatment arm.

QCA protocol. Aspirin (100 mg) and intravenous heparin (100 U/kg) were administered before coronary catheterisation. Coronary angiograms were performed by the conventional radial or femoral approach using a 6-F sheath and catheters after intracoronary nitrate administration. For QCA analysis we used a computer-based system QAngio XA version 7.0 (MEDIS Medical Imaging Systems Inc, Leiden, Netherlands) dedicated to straight segment and bifurcation analysis. Calibration of the system was based on catheter dimensions while unfilled with contrast medium. Two dimensional measurements were obtained in the stented segment and in $5 \mathrm{~mm}$ reference segments proximal and distal to the stent edge. The minimum lumen diameter (MLD) and reference vessel diameter (RVD) were measured from diastolic frames before and after the PCI procedure and at six months follow-up. Late lumen loss was defined as MLD post treatment minus MLD at follow-up, percent diameter stenosis (\%DS) was calculated as (1MLD/RVD) multiplied by 100 . \%DS is a comparison of two linear dimensions with a goal to obtain a surrogate measure of intimal hyperplasia thickness within the stent.

IVUS protocol. Following intracoronary nitrates IVUS images were acquired using automated pullback at $0.5 \mathrm{~mm} / \mathrm{s}$ speed aiming to start at least $10 \mathrm{~mm}$ distal and to end at least $10 \mathrm{~mm}$ proximal to the stent with the commercially available imaging system GALAXY II (Boston Scientific Corporation, Natick, Massachusetts, USA) at baseline and follow-up. In bifurcation lesions IVUS images of both main vessel and side branch were acquired. Two-dimensional and volumetric IVUS analysis was performed off-line using a computer-based quantitative analysis system (QCU-CMS version 4.14 MEDIS Medical Imaging Systems Inc, Leiden, Netherlands).
The lesion segment was classified as a culprit lesion with 5 $\mathrm{mm}$ of proximal and distal reference (most normal appearing) segments. Vessel, stent and lumen contours were automatically detected and manually corrected at 6-frame intervals; interpolated measurements of the remaining frames were automatically generated. Two dimensional analysis included minimum lumen diameter (MLD) and minimum lumen area (MLA). In-stent late loss in lumen diameter (or lumen area) was calculated as postprocedural lumen dimensions (MLD or MLA) minus follow-up dimensions (MLD or MLA). Three-dimensional (volumetric) analysis included vessel, plaque, stent, neointimal, and lumen volume measurements. Volume index was calculated as volume data divided by stent length to adjust volume measurement for stent length. Percent neointimal volume obstruction (\%NIV) was defined as the ratio of the volume of neointimal hyperplasia to the volume of the stent multiplied by 100 .

OCT protocol. An OCT catheter (Image Wire, Light Lab Imaging, Westford, Massachusetts) was advanced to the distal end of the culprit lesion. Once the image wire was positioned in the target vessel, it was pulled back at $2 \mathrm{~mm} / \mathrm{sec}$ speed. Pull-back was performed during simultaneous manual infusion of a viscous isosmolar infusion from the guiding catheter to remove the blood from the field of view. The OCT images were analysed with a computer-based quantitative analysis system (QCU-CMS version 4.14 MEDIS Medical Imaging Systems Inc, Leiden, Netherlands) dedicated for IVUS analysis. The areas and diameters of stent, lumen, and neointimal hyperplasia were measured every $1 \mathrm{~mm}$ within the stented segment. The neointimal coverage of stent struts were assessed every $1 \mathrm{~mm}$ within the stented segment. OCT and IVUS images were analysed by sideby-side viewing of follow-up studies, review of landmarks and pullback speed, frame-by-frame comparison for matching segments. Representative OCT and IVUS images obtained during follow-up angiography shown in Figure 1.

Statistics. Statistical analyses were performed using SPSS 12.0 for Windows (SPSS Inc., Chicago, IL, USA). Continuous variables were presented as mean \pm standard deviation and were compared using unpaired Student's t-test or Mann-Whitney rank-sum test, depending on variable distribution. Linear regression analysis was used to investigate the relationship between QCA and IVUS parameters and IVUS and OCT indexes. All statistical tests were 2-sided, and a $P$ value $<0.05$ was considered statistically significant. All data for QCA and IVUS refer to the offline analysis.

\section{RESULTS}

Two-hundred-sixty-one patients were included in our analysis. All patients had QCA and IVUS data. Of these, 20 patients had paired OCT and IVUS data. Baseline clinical, lesion and procedural characteristics of the study population are shown in Table 1. 


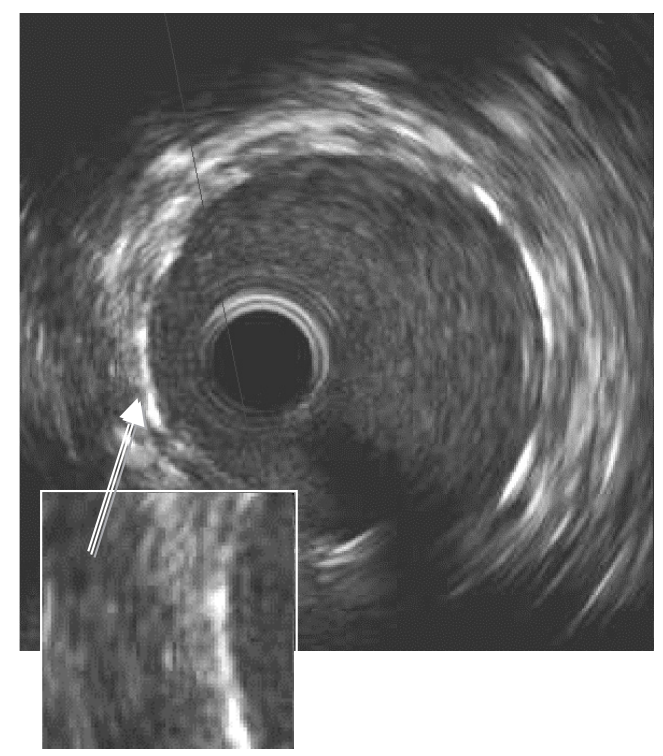

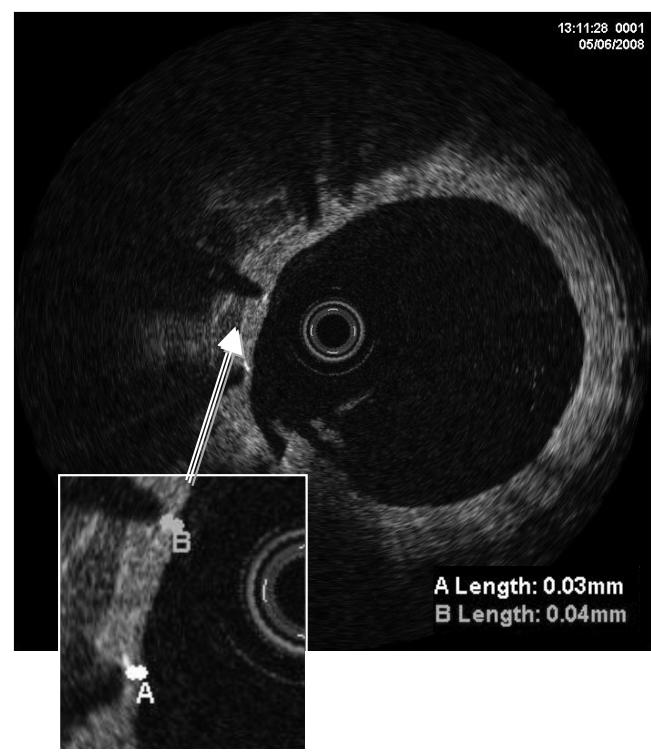

Ta ble 1
Fig. 1. Corresponding images by IVUS and OCT six months after DES implantation. Unlike OCT (right), there is no visually detectable neointimal proliferation in IVUS image (left).

Table 2

PATIENT, LESION AND PROCEDURAL CHARACTERISTICS

\begin{tabular}{ll}
\hline Patient and lesion number & 261 \\
Mean age, mean \pm SD (years) & $59.9 \pm 10.3$ \\
Male, n (\%) & $208(80)$ \\
Current smokers, n (\%) & $69(26)$ \\
Diabetes mellitus, n (\%) & $33(13)$ \\
Family history, n (\%) & $115(44)$ \\
Previous myocardial infarction, n (\%) & $144(55)$ \\
Hypertension, n (\%) & $150(58)$ \\
Hypercholesterolemia, n (\%) & $185(71)$ \\
Indication for PCI: & \\
$\quad$ Stable angina, n (\%) & $235(90)$ \\
$\quad$ Unstable angina, n (\%) & $14(5)$ \\
$\quad$ Acute myocardial infarction, n (\%) & $12(5)$ \\
Lesion location, n (\%): & $91(35)-116(44)-17$ (7) - 37 (14) \\
LM - LAD - Cx - RCA & \\
Lesion complexity, n (\%): & $161(62)-127$ (49) \\
$\quad$ Total occlusion - Bifurcation & $201(77)$ \\
Cutting balloon intervention, n (\%) & $163(62)-98$ (38) \\
Stenting, n (\%): DES - BMS &
\end{tabular}

BMS, bare metal stent; $\mathrm{Cx}$, circumflex artery; DES, drug eluting stent; LAD, left anterior descending artery; LM, left main; PCI, percutaneous coronary intervention, RCA, right coronary artery.

Angiographic and IVUS comparison at follow-up. The principal QCA and IVUS data acquired during follow-up are presented (Table 2).

There were statistically significant moderate correlations between corresponding two dimensional parameters (minimum lumen diameter and minimum lumen diameter late loss) by QCA and IVUS. Likewise moderate correlations were observed between two dimensional QCA parameters (MLD late loss, \% diameter stenosis) and three dimensional IVUS parameters ( $\%$ neointimal volume obstruction). A similar pattern of correlations was observed when we compared QCA and IVUS-derived data separately in patients after DES and BMS implantation. However, correlations
QCA AND IVUS PARAMETERS AT FOLLOW-UP

\begin{tabular}{l|c|c|c|c}
\hline & $\begin{array}{c}\text { Overall } \\
\mathrm{n}=261\end{array}$ & $\begin{array}{c}\text { DES patients } \\
\mathrm{n}=163\end{array}$ & $\begin{array}{c}\text { BMS patients } \\
\mathrm{n}=98\end{array}$ & $\begin{array}{c}P \text { value } \\
\text { (DES vs } \\
\text { BMS) }\end{array}$ \\
\hline \multicolumn{5}{c}{ QCA (in-stent) } \\
MLD & $2.3 \pm 0.7$ & $2.3 \pm 0.7$ & $2.4 \pm 0.7$ & $>0.05$ \\
\%DS & $22.8 \pm 17.0$ & $21.7 \pm 17.4$ & $25.2 \pm 16.0$ & $<0.05$ \\
MLD late loss & $0.4 \pm 0.7$ & $0.3 \pm 0.6$ & $0.6 \pm 0.8$ & $<0.01$ \\
& \multicolumn{5}{c}{ IVUS (in-stent) } \\
MLD & $2.7 \pm 0.5$ & $2.8 \pm 0.5$ & $2.7 \pm 0.5$ & $>0.05$ \\
MLD late loss & $0.3 \pm 0.4$ & $0.1 \pm 0.2$ & $0.6 \pm 0.4$ & $<0.001$ \\
MLA & $6.5 \pm 2.2$ & $6.1 \pm 2.0$ & $7.0 \pm 2.4$ & $<0.05$ \\
MLA late loss & $1.4 \pm 1.7$ & $0.6 \pm 0.9$ & $2.8 \pm 1.8$ & $<0.001$ \\
Intimal index & $1.2 \pm 1.6$ & $0.5 \pm 0.7$ & $2.3 \pm 1.9$ & $<0.001$ \\
\%NIV & $10.9 \pm 12.6$ & $5.8 \pm 7.7$ & $19.5 \pm 14.4$ & $<0.001$ \\
\end{tabular}

BMS, bare metal stent; DES, drug eluting stent; IVUS, intravascular ultrasound; MLA, minimum lumen area; MLD, minimum lumen diameter, QCA, quantitative coronary angiography; \%DS, percent diameter stenosis; $\% \mathrm{NIV}$, percent neointimal volume obstruction.

within the BMS group tended in general to be stronger than within the DES group (see Table 3).

When we compared QCA and IVUS parameters in DES versus BMS patients, the statistical significance was noted in both QCA and IVUS indexes (Table 3). However, when we compared DES and BMS groups in different subsets of lesions, the QCA indexes for patients with chronic total occlusions did not differ significantly between BMS and DES groups unlike IVUS parameters (Table 4).

IVUS and OCT comparison at follow-up. OCT images were acquired in 20 patients with left main disease and compared to IVUS images obtained during the same angiography procedure. Two patients were excluded from OCT analysis because of incomplete image acquisition. Analyzable OCT images were acquired in 18 patients. We compared 200 corresponding IVUS and OCT cross-sectional 
Table 3

QCA VERSUS IVUS CORRELATIONS AT FOLLOW-UP

\begin{tabular}{l|c}
\hline & $\mathrm{r}$ \\
\hline MLD (QCA) vs MLD (IVUS) & 0.488 \\
Overall & 0.544 \\
BMS & 0.451 \\
DES & \\
\hline MLD loss (QCA) vs MLD loss (IVUS) & 0.450 \\
Overall & 0.323 \\
BMS & 0.361 \\
DES & \\
\hline MLD loss (QCA) vs \%NIV (IVUS) & 0.422 \\
Overall & 0.388 \\
BMS & 0.379 \\
DES & \\
\hline \%DS (QCA) vs \%NIV (IVUS) & 0.384 \\
Overall & 0.472 \\
BMS & 0.416 \\
DES &
\end{tabular}

$P$ value was $<0.001$; BMS, bare metal stent; DES, drug eluting stent; IVUS, intravascular ultrasound; MLD, minimum lumen diameter, QCA, quantitative coronary angiography; \%DS, percent diameter stenosis; $\%$ NIV, percent neointimal volume obstruction.

Ta b le 4

QCA AND IVUS PARAMETERS AT FOLLOW-UP IN SUB-POPULATIONS

\begin{tabular}{l|c|c|c|c|c|c}
\hline \multirow{2}{*}{} & \multicolumn{2}{c|}{ Left main lesions N=91 } & \multicolumn{2}{c}{ Total occlusions N=161 } \\
\cline { 2 - 7 } & $\begin{array}{c}\text { DES } \\
\mathrm{n}=48\end{array}$ & $\begin{array}{c}\text { BMS } \\
\mathrm{n}=43\end{array}$ & $P$ value & $\begin{array}{c}\text { DES } \\
\mathrm{n}=100\end{array}$ & $\begin{array}{c}\text { BMS } \\
\mathrm{n}=61\end{array}$ & $P$ value \\
\hline \multicolumn{7}{c}{ QCA (in-stent) } \\
\hline \%DS & $15.9 \pm 9.3$ & $\begin{array}{c}22.3 \pm \\
15.7\end{array}$ & $<0.05$ & $\begin{array}{c}25.7 \pm \\
19.1\end{array}$ & $\begin{array}{c}24.0 \pm \\
15.9\end{array}$ & $>0.05$ \\
\hline MLD late loss & $0.3 \pm 0.4$ & $0.5 \pm 0.7$ & $<0.05$ & $0.4 \pm 0.7$ & $0.5 \pm 0.8$ & $>0.05$ \\
\hline \multicolumn{7}{|c|}{ IVUS (in-stent) } \\
\hline MLD late loss & $0.2 \pm 0.2$ & $0.6 \pm 0.3$ & $<0.001$ & $0.2 \pm 0.3$ & $0.6 \pm 0.4$ & $<0.001$ \\
\hline MLA late loss & $1.0 \pm 0.9$ & $2.7 \pm 1.5$ & $<0.001$ & $1.0 \pm 1.0$ & $2.7 \pm 1.7$ & $<0.001$ \\
\hline Intimal index & $0.8 \pm 0.6$ & $1.9 \pm 1.2$ & $<0.001$ & $0.8 \pm 0.8$ & $2.1 \pm 1.7$ & $<0.001$ \\
\hline NIV & $7.5 \pm 6.9$ & $16.2 \pm$ & $<0.05$ & $8.9 \pm 8.2$ & $18.1 \pm$ & $<0.05$ \\
& & 10.7 & & & 12.7 &
\end{tabular}

BMS, bare metal stent; DES, drug elutin stent; IVUS, intravascular ultrasound; MLA, minimum lumen area; MLD, minimum lumen diameter, QCA, quantitative coronary angiography; \%DS, percent diameter stenosis; $\%$ NIV, percent neointimal volume obstruction.

images. The mean minimum lumen diameter was $3.2 \pm 0.4$ $\mathrm{mm}$ by both IVUS and OCT. The mean minimum lumen area was $8.1 \pm 1.8 \mathrm{~mm}^{2}$ by IVUS and $8.1 \pm 2.2 \mathrm{~mm}^{2}$ by OCT. The correlations between IVUS and OCT measurements were strong and significant (Figs. 2 and 3). However, when we compared the degree of stent endothelisation by IVUS and OCT, total number of uncovered stent struts per image was $0.4 \pm 0.8$ by OCT and $1.2 \pm 1.5$ by IVUS $(P<$ $0.001)$.

\section{DISCUSSION}

Intravascular ultrasound is an important tool for confirming the presence of significant stenosis in left main or other

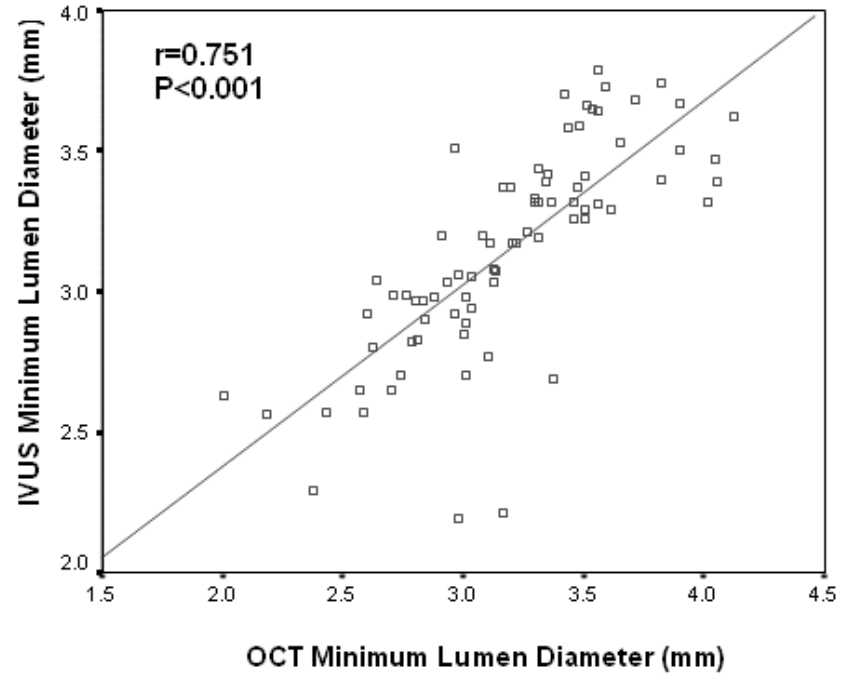

Fig. 2. Correlation of IVUS minimum lumen diameter versus OCT lumen diameter.

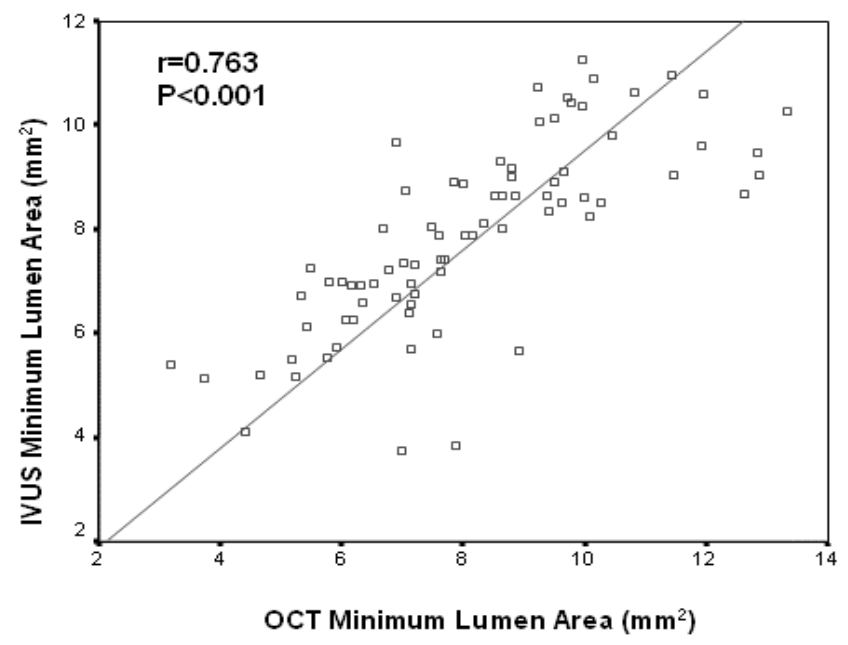

Fig. 3. Correlation of IVUS minimum lumen area versus OCT lumen area.

complex lesions and also for guiding selection of stent size, assessing the presence of calcification, and documenting the involvement of the distal left main vessel and its branches. Intravascular ultrasound measurement of minimum lumen diameter and area stenosis was shown as the most important quantitative predictor of cardiac events (Abizaid et al., 1999).

The main finding of our study was that two-dimensional and three-dimensional (volumetric) IVUS parameters correlate with two dimensional QCA indexes after complex lesion intervention. Although they assess the same biologic process, our study showed only a moderate relation between QCA and IVUS parameters. The most commonly used angiographic endpoint in randomised clinical trials are late lumen loss and \% diameter stenosis (Mauri et al., 2005; Pocock et al., 2008). Our analysis showed that \%DS correlated with \%NIV with an $r$ value of 0.384 overall, 0.472 for BMS and 0.416 for DES. Our data is consistent with data from meta-analysis by Escolar et al. (2007). However, some 
randomised studies have showed stronger correlation between QCA and IVUS (Park et al., 2003; Mintz et al., 2005). The probable explanation is the difference in lesion characteristics and the reduced total degree of neointimal proliferation in our study. \%NIV even in the BMS population in our study was lower $(19.5 \pm 14.4$ our study vs. 29.1 \pm 19.2 ASPECT study) (Mintz et al., 2005). We can speculate that this is a result of plaque pretreatment with cutting balloon before stent implantation (Erglis et al., 2007). In our study $77 \%$ patients underwent cutting balloon intervention before stent implantation.

It is well-known that DES implantation reduces neointimal proliferation (Sousa et al., 2001). The benefit of DES implantation with regard to neointimal proliferation was observed in our study overall $(n=261)$ and in the subset of patients with left main coronary artery disease $(n=98)$. Yet in the subset of patients with chronic total occlusions ( $\mathrm{n}=$ 161) there was statistically significant less neointima by IVUS parameters in DES compared to BMS while QCA parameters were similar in both groups. We can assume that IVUS is more accurate tool for assessment of neointimal proliferation. With intravascular ultrasound measurements compared to QCA smaller sample sizes should be necessary to show a significant reduction in in-stent neointimal tissue accumulation.

The second main finding of our study was that there was a strong correlation between IVUS and OCT parameters. This corresponds to findings in other trials (Yamaguchi et al., 2008). However, when we compared stent strut coverage with neointimal tissue there were more uncovered struts per one IVUS image compared to OCT. We can assume that often the assessment of stent endothelisation is below the resolution of IVUS. Although OCT was superior to IVUS in visualisation of microscopic structures of the coronary arteries, an important limitation of this technique is the need to displace blood during OCT image acquisition and substantial signal attenuation of the OCT source light, and low penetration of the signal. Therefore, in our small subset of patients with large vessel (left main) disease complete image acquisition was impossible in two patients (10\%).

The present study was carried out in a retrospective manner. Small inaccuracies cannot be completely ruled out because of the absence of dedicated software for OCT analysis and IVUS bifurcation analysis.

In conclusion, QCA and IVUS measures of lumen dimensions correlated at single time points. Angiographic \% diameter stenosis correlates moderately with \% neointimal volume obstruction by IVUS in our study population. However, intravascular ultrasound measurements of neointimal hyperplasia use superior to QCA for assessing the effect of different stenting strategies on in-stent neointimal tissue accumulation and in-stent restenosis while OCT was a more accurate tool for evaluation of stent endothelisation. Therefore, the use of IVUS and OCT should be encouraged in comparison studies aimed at revealing significant neointimal differences in small sample size populations.

\section{ACKNOWLEDGMENT}

The work was supported by the National Research Programme in Medicine 2006-2009, project $n r$. 1, „Elaboration of new methods of early diagnostics, prevention and treatment of cardiovascular diseases".

We gratefully acknowledge the Innovative Medical Foundation for providing financial support.

\section{REFERENCES}

Abizaid, A.S., Mintz, G.S., Abizaid, A., Mehran, R., Lansky, A.J., Pichard, A.D., Satler, L.F., Wu, H., Kent, K.M., Leon, M.B. (1999). One-year follow-up after intravascular ultrasound assessment of moderate left main coronary artery disease in patients with ambiguous angiograms. J. Amer. Coll. Cardiol., 34(3), 707-715.

Erglis, A., Narbute, I., Kumsars, I., Jegere, S., Mintale, I., Zakke, I., Strazdins, U., Saltups, A. (2007). A randomized comparison of paclitaxel-eluting stents versus bare-metal stents for treatment of unprotected left main coronary artery stenosis. J. Amer. Coll. Cardiol., 50(6), 491-497.

Escolar, E., Mintz, G.S., Popma, J., Michalek, A., Kim, S.W., Mandinov, L., Koglin, J., Stone, G., Ellis, S.G., Grube, E., Dawkins, K.D., Weissman, N.J. (2007). Meta-analysis of angiographic versus intravascular ultrasound parameters of drug-eluting stent efficacy (from TAXUS IV, V, and VI). Amer. J. Cardiol., 100(4), 621-626.

Honda, Y., Fitzgerald, P.J. (2008). Frontiers in intravascular imaging technologies. Circulation, 117(15), 2024-2037.

Joner, M., Finn, A.V., Farb, A., Mont, E.K., Kolodgie, F.D., Ladich, E., Kutys, R., Skorija, K., Gold, H.K., Virmani, R. (2006). Pathology of drug-eluting stents in humans: Delayed healing and late thrombotic risk. $J$. Amer. Coll. Cardiol., 48(1), 193-202.

Kawasaki, M., Takatsu, H., Noda, T., Ito, Y., Kunishima, A., Arai, M., Nishigaki, K., Takemura, G., Morita, N., Minatoguchi, S., Fujiwara, H. (2001). Noninvasive quantitative tissue characterization and two-dimensional color-coded map of human atherosclerotic lesions using ultrasound integrated backscatter: Comparison between histology and integrated backscatter images. J. Amer. Coll. Cardiol., 38(2), 486-492.

Luscher, T.F., Steffel, J., Eberli, F.R., Joner, M., Nakazawa, G., Tanner, F.C., Virmani, R. (2007). Drug-eluting stent and coronary thrombosis: Biological mechanisms and clinical implications. Circulation, 115(8), 1051-1058.

Mauri, L., Orav, E.J., O'Malley, A.J., Moses, J.W., Leon, M.B., Holmes, D.R., Jr., Teirstein, P.S., Schofer, J., Breithardt, G., Cutlip, D.E., Kereiakes, D.J., Shi, C., Firth, B.G., Donohoe, D.J., Kuntz, R.E. (2005). Relationship of late loss in lumen diameter to coronary restenosis in sirolimus-eluting stents. Circulation, 111(3), 321-327.

Mintz, G.S., Hong, M.K., Raizner, A.E., Lee, C.W., Kim, J.J., Escolar, E., Fearnot, N.E., Park, S.W., Park, S.J., Weissman, N.J. (2005). Comparison of quantitative angiographic parameters with the magnitude of neointimal hyperplasia measured by volumetric intravascular ultrasound in patients treated with bare metal and nonpolymeric paclitaxel-coated stents. Amer. J. Cardiol., 95(1), 105-107.

Morice, M.-C., Serruys, P.W., Sousa, J.E., Fajadet, J., Ban Hayashi, E., Perin, M., Colombo, A., Schuler, G., Barragan, P., Guagliumi, G., Molnar, F., Falotico, R., the, R.S.G. (2002). A randomized comparison of a sirolimus-eluting stent with a standard stent for coronary revascularization. New Engl. J. Med., 346 23), 1773-1780.

Nasu, K., Tsuchikane, E., Katoh, O., Vince, D.G., Virmani, R., Surmely, J.-F., Murata, A., Takeda, Y., Ito, T., Ehara, M., Matsubara, T., Terashima, M., Suzuki, T. (2006). Accuracy of in vivo coronary plaque morphology assessment: A validation study of in vivo virtual histology compared with in vitro histopathology. J. Amer. Coll. Cardiol., 47(12), 2405-2412. 
Park, S.-J., Shim, W.H., Ho, D.S., Raizner, A.E., Park, S.-W., Hong, M.-K., Lee, C.W., Choi, D., Jang, Y., Lam, R., Weissman, N.J., Mintz, G.S. (2003). A paclitaxel-eluting stent for the prevention of coronary restenosis. New Engl. J. Med., 348(16), 1537-1545.

Pocock, S.J., Lansky, A.J., Mehran, R., Popma, J.J., Fahy, M.P., Na, Y., Dangas, G., Moses, J.W., Pucelikova, T., Kandzari, D.E., Ellis, S.G., Leon, M.B., Stone, G.W. (2008). Angiographic surrogate end points in drugeluting stent trials: A systematic evaluation based on individual patient data from 11 randomized, controlled trials. J. Amer. Coll. Cardiol., 51(1), 23-32.

Semeraro, O., Agostoni, P., Verheye, S., Van Langenhove, G., Van den Heuvel, P., Convens, C., Van den Branden, F., Bruining, N., Vermeersch, P. (2009) Re-examining minimal luminal diameter relocation and quantitative coronary angiography-intravascular ultrasound correlations in stented saphenous vein grafts: Methodological insights from the randomised RRISC trial. EuroIntervention, 4(5), 633-640.

Serruys, P.W., Kutryk, M.J.B., Ong, A.T.L. (2006). Coronary-artery stents. New Engl. J. Med., 354(5), 483-495.

Received 11 July 2009
Sousa, J.E., Costa, M.A., Abizaid, A., Abizaid, A.S., Feres, F., Pinto, I.M.F., Seixas, A.C., Staico, R., Mattos, L.A., Sousa, A.G.M.R., Falotico, R., Jaeger, J., Popma, J.J., Serruys, P.W. (2001). Lack of neointimal proliferation after implantation of sirolimus-coated stents in human coronary arteries : A quantitative coronary angiography and three-dimensional intravascular ultrasound study. Circulation, 103(2), 192-195.

Tearney, G.J., Yabushita, H., Houser, S.L., Aretz, H.T., Jang, I.-K., Schlendorf, K.H., Kauffman, C.R., Shishkov, M., Halpern, E.F., Bouma, B.E. (2003). Quantification of macrophage content in atherosclerotic plaques by optical coherence tomography. Circulation, 107(1), 113-119.

Weintraub, W.S. (2007). The pathophysiology and burden of restenosis. Amer. J. Cardiol., 100(5A), 3K-9K.

Yamaguchi, T., Terashima, M., Akasaka, T., Hayashi, T., Mizuno, K., Muramatsu, T., Nakamura, M., Nakamura, S., Saito, S., Takano, M., Takayama, T., Yoshikawa, J., Suzuki, T. (2008). Safety and feasibility of an intravascular optical coherence tomography image wire system in the clinical setting. Amer. J. Cardiol., 101(5), 562-567.

Yock, P.G., Linker, D.T., Angelsen, B.A. (1989). Two-dimensional intravascular ultrasound: Technical development and initial clinical experience. J. Amer. Soc. Echocardiogr., 2(4), 296-304.

\section{INTRAVASKULĀRĀS ATTĒLDIAGNOSTIKAS UN KVANTITATĪVĀS KORONĀRĀS ANGIOGRĀFIJAS SALĪDZINĀJUMS NEOINTİMAS NOVĒRTĒŠANAI PĒC STENTA IMPLANTĀCIJAS SAREŽĢĪTOS KORONĀRO ARTËRIJU BOJĀJUMOS}

Ar intravaskulārās attēldiagnostikas metodēm, atškirībā no kvantitatīvās koronārās angiogrāfijas $(Q C A)$, ir iespējams vizualizēt artērijas sieniņu. Mūsu mērķis bija salīdzināt dažādus neointīmu raksturojošus intravaskulārās ultraskaņas (IVUS) un optiskās koherences tomogrāfijas $(O C T)$ parametrus ar QCA rādītājiem pacientiem pēc intervences sarežğîtos koronāros bojājumos. Mēs analizējām 261 pacientu, kam veikta perkutāna koronāra intervence sarežğîtos bojājumos ar parasta metāla (BMS) vai zālēm pildīta stenta (DES) implantāciju un sešu mēnešu apsekošanas angiogrāfijas laikā veikta IVUS vai $O C T$. Procentuālā diametra stenoze (QCA) bija 25,2 $\pm 16,0$ $B M S$ un 21,7 $\pm 17,4$ DES grupās $(P<0,05)$. Procentuālā neointīmas tilpuma obstrukcija (IVUS) bija 19,5 $\pm 14,4$ BMS un 5,8 $\pm 7,7$ DES grupā $(P<0,001)$. Pacientiem ar hroniskām totālām oklūzijām $(\mathrm{n}=161) Q C A$ parametrs bija līdzīgs abās grupās $(P>0,05)$, bet IVUS neointīmu novēroja mazāk DES grupā $(P<0,05)$. Starp QCA un IVUS novēroja mērenu korelāciju ar $\mathrm{r}$ vērtību 0,384 kopējā populācijā, $0,472 B M S$ un 0,416 DES grupās ( $P<0,001$ visās populācijās). Kopējais nepārklāto stenta šūnu skaits uz vienu $O C T$ attēlu bija $0,4 \pm 0,8$, bet uz vienu IVUS attēlu $1,2 \pm 1,5(P<0,001)$. Angiogrāfiskie rādītāji korelē ar volumetriskajiem intravaskulārajiem rādītājiem. Tomēr IVUS ir daudz jūtīgāka metode nekā $Q C A$ neointīmas proliferācijas novērtēšanai, savukārt OCT ir jūtīgāka stenta endotelizācijas novērtēšanai. 